Please do not remove this page

RMIT

UNIVERSITY

\title{
Single capstone or multiple cornerstones? Distributed model of capstone subjects in construction education
}

Arashpour, Mehrdad; Sagoo, Amrit; Wingrove, Dallas; Maqsood, Tayyab; Wakefield, Ronald https://researchrepository.rmit.edu.au/esploro/outputs/9921860291701341/filesAndLinks?institution=61RMIT_INST\&index=null

Arashpour, M., Sagoo, A., Wingrove, D., Maqsood, T., \& Wakefield, R. (2015). Single capstone or multiple cornerstones? Distributed model of capstone subjects in construction education. Proceedings of the Eighth International Structural Engineering and Construction Conference (ISEC-8), 1-6.

https://doi.org/10.14455/ISEC.res.2015.27

Document Version: Published Version

Published Version: https://doi.org/10.14455/ISEC.res.2015.27

Repository homepage: https://researchrepository.rmit.edu.au

Copyright (c) 2015 ISEC Press

Downloaded On 2023/04/26 22:05:28 +1000 
Thank you for downloading this document from the RMIT Research Repository.

The RMIT Research Repository is an open access database showcasing the research outputs of RMIT University researchers.

RMIT Research Repository: http://researchbank.rmit.edu.au/

\section{Citation:}

Arashpour, M, Sagoo, A, Wingrove, D, Maqsood, T and Wakefield, R 2015, 'Single capstone or multiple cornerstones? Distributed model of capstone subjects in construction education', in Saha, S., Zhang, Y., Yazdani, S., and Singh, A. (ed.) Proceedings of the Eighth International Structural Engineering and Construction Conference (ISEC-8), Fargo, United States, 23-28 November 2015, pp. 1-6.

See this record in the RMIT Research Repository at:

https://researchbank.rmit.edu.au/view/rmit:34766

Version: Published Version

Copyright Statement: (c) 2015 ISEC Press

Link to Published Version:

http://dx.doi.org/10.14455/ISEC.res.2015.27

\section{PLEASE DO NOT REMOVE THIS PAGE}




\title{
SINGLE CAPSTONE OR MULTIPLE CORNERSTONES? CONSOLIDATING LEARNING WITH A DISTRIBUTED MODEL OF CAPSTONE SUBJECTS IN CONSTRUCTION EDUCATION
}

\author{
MEHRDAD ARASHPOUR ${ }^{1}$, AMRIT SAGOO ${ }^{2}$, DALLAS WINGROVE ${ }^{3}$, \\ TAYYAB MAQSOOD ${ }^{4}$, RON WAKEFIELD ${ }^{5}$ \\ ${ }^{1-5}$ School of Property, Construction and Project Management, RMIT University, Melbourne, \\ Australia
}

\begin{abstract}
Capstone experiences provide critical opportunities for undergraduate students to integrate and apply the skills and knowledge they have previously developed in their degree or program. Commonly, this involves students engaging in learning experiences that involve real-world issues and which in turn enhance the student experience and employability skills. The research on capstone experiences in the construction management education literature indicates a need to develop customized delivery models that addresses the specific requirements of construction industry and education providers. This paper aims to showcase an innovative model of distributed delivery for multiple capstones (cornerstones) in a construction management program. The case study described in this paper realized an improvement in capstone design and practicebased learning by incrementally enhancing a student's knowledge of construction project management skills. The model of multiple capstones discussed here is applicable to diverse disciplines, including construction engineering and management programs.
\end{abstract}

Keywords: Construction engineering and management, Cornerstones, Distributed capstones, Global learning by design, Pedagogy, Project-based learning, Studentcentered learning

\section{INTRODUCTION}

Construction education has been known for its innovation in delivering industry-ready graduates who meet diverse industry demands. Part of this success is the result of using practice-based education in construction management programs. Capstone subjects, for instance, offer a range of experiences that lie outside the purview of traditional construction management subjects. Capstone courses are important in development of skills that are required by construction industry and core competencies stipulated by industry's professional institutions (McIntyre 2002, Arashpour, Shabanikia et al. 2012). A wide range of pedagogical philosophies have been utilized in developing and delivering final-year capstones. Active learning, project-based learning, and work-based learning are three prevalent approaches used for this purpose (MacDonald and Mills 2013, Arashpour, Wakefield et al. 2013b). Traditionally, the capstone subject is embedded in the final year to conclude the academic experience. Despite the success of final-year capstone subjects in numerous curriculum areas, there have been criticisms in the construction education domain about associated issues such as heavy workload for 
senior students and limited student-practitioner interactions (Kift S, Butler D et al. 2013, Arashpour and Arashpour 2015a). Very few studies have explored the potential of using an alternative model to final-year capstone experiences in order to develop a tailored pedagogical approach for construction education.

The aim of this paper is to showcase a distributed model of capstone subjects (cornerstones) and describe the lessons learned from implementation of the model in the construction management program in the authors' university. In this distributed model, rather than having one capstone course towards the end of the degree program, students engage in a capstone subject across 3 year levels. In order to examine the efficacy and applicability of a cornerstone approach to capstones, this paper provides a review of pedagogical literature relating to the design and implementation of capstones. The authors also examine the challenges inherent in integrating final-year capstones into curriculum. Finally, the lessons learned as part of delivery process are discussed.

\section{THEORETICAL BACKGROUND}

Previous research in higher education literature has shown that integration of capstone courses into a program or degree enhances the structure of a program and supports students to synthesize their prior learning and knowledge (Goldberg 2012, Arashpour, Wakefield et al. 2013a). This section of the paper, presents existing ways of integrating capstones into the curriculum that have been identified in the literature.

There are variety of paradigms in the higher education literature that support the design and implementation of capstone subjects. These pedagogical paradigms along with potential challenges have been illustrated in Figure 1.

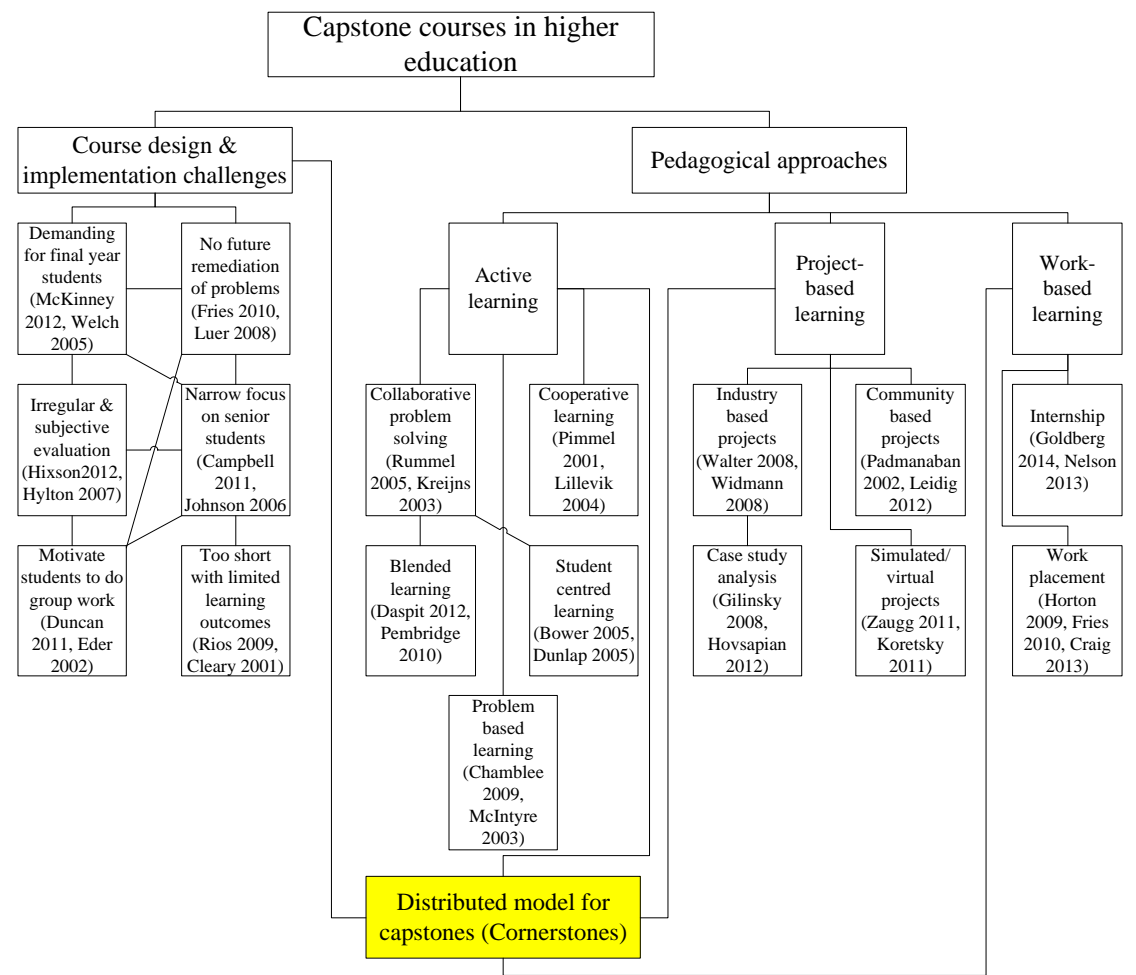

Figure 1. Pedagogical approaches used in capstone experiences and potential challenges 


\section{DESIGNING AND IMPLEMENTING THE DISTRIBUTED MODEL OF CAPSTONE SUBJECTS: INTRODUCING THE CORNERSTONES}

\subsection{The Context}

In order to address the challenges in developing and delivering final-year capstones, a new distributed model of capstones was implemented in the context of a Construction Management program at the authors' university. Rather than placing one capstone subject at the end of the degree program, three capstones (cornerstones) are embedded at each year level. Construction Planning and Design (CPD) subjects are offered at the second, third and fourth year of the program. CPD1 (BUIL1245), CPD2 (BUIL1256) and CPD3 (BUIL1262) are embedded in second semesters in order to reinforce the student learning over the four courses in the first semester in the related year level. The three capstone courses (cornerstones) are designed to incrementally build up knowledge as year level advances and are in line with Blooms Taxonomy and requirements of Australian Qualifications Framework (Arashpour, Wakefield et al. 2014b). Figure 2 illustrates the distributed model of cornerstones used in the Construction Management program.

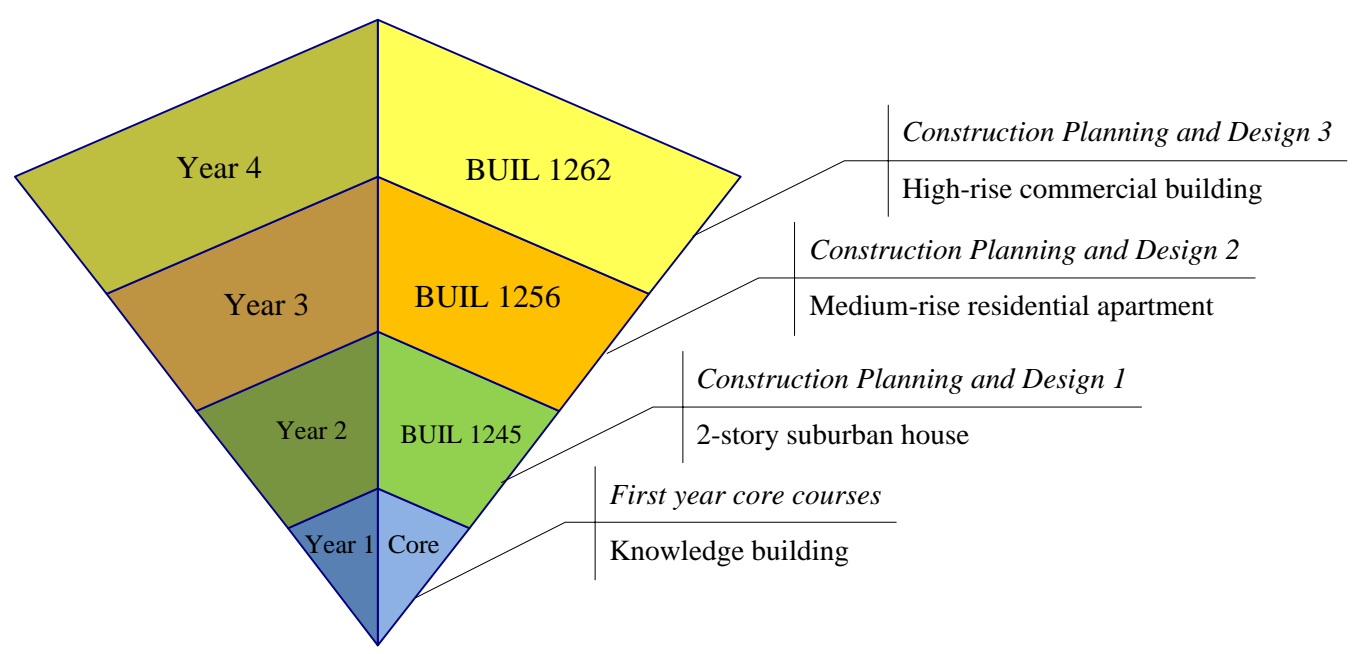

Figure 2. Distributed model of cornerstones in the construction management program

\subsection{Incremental Knowledge Building in Cornerstone Courses}

In the construction Planning and Design (CPD) courses, students analyse and discuss how construction techniques, measurement, estimating and process planning apply to industry specific problem-based scenarios. This scenario is a two-story suburban house in the second-year cornerstone. In third year and fourth year, a medium-rise residential apartment with basement and a high-rise commercial building is analysed respectively. The expected learning outcomes of the three courses are presented in table 4 . 
Table 1. Learning outcomes and benefits of cornerstones in the studied construction management program

\begin{tabular}{|c|c|}
\hline Course & Learning outcomes \\
\hline \multirow{4}{*}{$\begin{array}{l}\text { Construction } \\
\text { and design } 1\end{array}$} & Estimate and plan the construction of a building \\
\hline & Describe the processes and technologies of construction \\
\hline & Utilise production planning methods using project documentation \\
\hline & Discuss how building systems interface and are constructed \\
\hline \multirow[t]{4}{*}{$\begin{array}{l}\text { Construction } \\
\text { and design } 2\end{array}$} & $\begin{array}{l}\text { Determine and apply complex construction management theory to the } \\
\text { professional practice and/or further study }\end{array}$ \\
\hline & $\begin{array}{l}\text { Professionally communicate to a range of audiences, demonstrating in depth } \\
\text { knowledge of the discipline and of the needs of diverse construction } \\
\text { management stakeholders }\end{array}$ \\
\hline & $\begin{array}{l}\text { Apply logical critical and creative thinking to analyse, synthesise and apply } \\
\text { theoretical knowledge and technical skills to formulate evidenced based } \\
\text { solutions to industry problems or issues }\end{array}$ \\
\hline & $\begin{array}{l}\text { Collaborate effectively with others and demonstrate intellectual independence } \\
\text { and autonomy to solve problems and/or address industry issues or imperatives }\end{array}$ \\
\hline \multirow[t]{5}{*}{$\begin{array}{l}\text { Construction } \\
\text { and design } 3\end{array}$} & $\begin{array}{l}\text { Integrate and apply specialised construction management skills to a current } \\
\text { construction project }\end{array}$ \\
\hline & $\begin{array}{l}\text { Develop solutions to identified problems using conflict resolution skills, } \\
\text { relevant policy and regulatory frameworks including } \mathrm{OH} \& \mathrm{~S}\end{array}$ \\
\hline & $\begin{array}{l}\text { Apply theoretical specialised knowledge to address problem based case } \\
\text { studies in construction management }\end{array}$ \\
\hline & $\begin{array}{l}\text { Undertake independent research and apply analytical skills to produce tender } \\
\text { submissions }\end{array}$ \\
\hline & Lead and contribute to professional discussions \\
\hline
\end{tabular}

Appropriate class activities and assessment tasks have been designed for cornerstones that are proportional to the complexity level of the courses. For example, in Construction Planning and Design 2, all building documentations for a medium-rise development are given to students. A new worksite related problem is introduced to students every week and they are required to deal with it as construction managers. As the construction literature suggest, these educational problems include but are not limited to low production rates (AbouRizk, Knowles et al. 2001, Lee, Fung et al. 2013), variability and uncertainty in processes (Arashpour, Wakefield et al. 2013c), waste in construction (Chan, Yuen et al. 2015), and quality problems and rework (Arashpour, Wakefield et al. 2014a). The final report for the capstone project over 12 weeks looks like the diary of a construction manager.

\section{SUMMARY AND LESSONS LEARNED}

By addressing the challenges in developing and delivering capstone subjects, the case study described in this manuscript realized an improvement in the current state of practice-based learning in construction education. As a result, several lessons were learned from implementing the distributed model of cornerstones, including the following:

- Using multiple cornerstones at different year levels in the construction management program helped students to reinforce their learning over the course of study by overcoming the forgetting curve.

- Harnessing the distributed model of capstones in curriculum design facilitates delivering cutting-edge and innovative construction education. Several instances of 
interaction with industry mentors benefitted students in understanding contemporary issues of the construction industry.

- Initially more time and resources were used to set up multiple cornerstones. However, after this developing stage, the delivery stage was smooth with both students and academic staff realizing time savings.

- Despite the overwhelming success of onshore cornerstone delivery, some challenges were observed in offshore delivery. It was found necessary to coordinate lecturing staff and develop localised project-based scenarios in order to ensure quality learning outcomes in offshore delivery.

- Using internet-based tools in developing course content for blended delivery developed the online learning capacity for both students and staff. This improvement facilitated the processes of knowledge sharing and also showcasing student's works

-Working on real-world project scenarios in cornerstones enhanced the student knowledge of construction project management skills. These skills are closely linked to the core competencies stipulated by construction industry's professional institutions such as RICS, CIOB and AIB.

This model of cornerstone capstones can be applied within and beyond construction management (Arashpour, Wakefield et al. 2015b). As this paper has explored, combining active learning and project-based learning provides multiple channels for enhancing student learning experience. In order to deepen understandings of the value of a cornerstone model for our students it is imperative is to more fully explore the student learning journey; student's perceptions of their learning (Arashpour, Wakefield et al. 2015c). What must also be explored is what combination of curriculum and pedagogic practices are conducive to a meaningful, rich and beneficial capstone experience for our students as we prepare them for their future professional practice. Only then can we optimize and enhance through a capstone delivery students' learning and experience of higher education.

\section{References}

AbouRizk, S., P. Knowles and U. Herman (2001). "Estimating Labor Production Rate for Industrial Construction Activities." Journal of construction engineering and management 127(6): 502-511.

Arashpour, M. and M. Arashpour (2015a). "Analysis of Workflow Variability and Its Impacts on Productivity and Performance in Construction of Multistory Buildings." Journal of Management in Engineering: DOI: 10.1061/(ASCE)ME.1943-5479.0000363.

Arashpour, M., M. Shabanikia and M. Arashpour (2012). "Valuing the contribution of knowledge-oriented workers to projects: A merit based approach in the construction industry." Australasian Journal of Construction Economics and Building 12(4): 1-12.

Arashpour, M., R. Wakefield and N. Blismas (2013a). Role of simulation in construction processes-harmony in capturing resources. Research, Development and Practice in Structural Engineering and Construction (ASEA-SEC), Research Publishing Services (RPS). 
Arashpour, M., R. Wakefield and N. Blismas (2013b). Improving construction productivity: implications of even flow production principles. CIB World Building Congress 2013: Construction and Society, Queensland University of Technology.

Arashpour, M., R. Wakefield, N. Blismas and E. W. M. Lee (2013c). "A new approach for modelling variability in residential construction projects." Australasian Journal of Construction Economics and Building 13(2): 83-92.

Arashpour, M., R. Wakefield, N. Blismas and E. W. M. Lee (2014a). "Analysis of disruptions caused by construction field rework on productivity in residential projects." Journal of Construction Engineering and Management 140(2): 1-12.

Arashpour, M., R. Wakefield, N. Blismas and E. W. M. Lee (2014b). "Framework for improving workflow stability: Deployment of optimized capacity buffers in a synchronized construction production." Canadian Journal of Civil Engineering 41(12): 995-1004.

Arashpour, M., R. Wakefield, N. Blismas and T. Maqsood (2015b). "Autonomous production tracking for augmenting output in off-site construction." Automation in Construction 53(0): 13-21.

Arashpour, M., R. Wakefield, N. Blismas and J. Minas (2015c). "Optimization of process integration and multi-skilled resource utilization in off-site construction." Automation in Construction 50(1): 72-80.

Chan, R. W. K., J. K. K. Yuen, E. W. M. Lee and M. Arashpour (2015). "Application of Nonlinear-Autoregressive-Exogenous model to predict the hysteretic behaviour of passive control systems." Engineering Structures 85(1): 1-10.

Goldberg, J. R. (2012). "Active learning in capstone design courses." IEEE Pulse 3(3): 5457.

Kift S, Butler D, R. Field, J. McNamara and Brown C (2013). Curriculum renewal in legal education. Sydney Australian Government 143.

Lee, E. W. M., I. W. H. Fung, V. W. Y. Tam and M. Arashpour (2013). "A fully autonomous kernel-based online learning neural network model and its application to building cooling load prediction." Soft Computing: 1-16.

MacDonald, J. and J. Mills (2013). "An IPD approach to construction education." Australasian Journal of Construction Economics and Building 13(2): 93-103.

McIntyre, C. (2002). Problem-based learning as applied to the construction and engineering capstone course at North Dakota State University. 23nd Annual Frontiers in Education; Leading a Revolution in Engineering and Computer Science Education, Boston, MA. 